\title{
Laboratory apparatus calling
}

\section{Eleven new products are described this month including a device that "phones} home" when your experiment goes wrong.

- The Accuspec "second generation" compact gas chromatograph measures only $12 \frac{1}{2} 2^{\prime \prime} \times 12 \frac{1}{2} 2^{\prime \prime} \times 15 \frac{1}{2} 2^{\prime \prime}$ high yet offers research-grade performance and a full range of features. The full dual column oven provides a choice of three capillary systems or $1 / 8$ " packed column facilities. Automatic cooldown is standard with the temperature programmer. Dual FID, micro-TCD and specific detectors are available.

Circle No. 140 on Reader Service Card.

- The Laser Analytics Division of Spectra-Physics Inc. has developed a cleaved-coupled-cavity $\mathrm{Pb}$-salt diode laser that operates single mode over limited current and temperature ranges. The new device consists of two coupled cavity sections: the front section performs as an emitting laser and the rear section as a modulator. By varying the modulator current, it is possible to tune the emission from the front section thereby obtaining additional precise control of the laser emission characteristics.

Circle No.141 on Reader Service Card.

- Perkin-Elmer's LC-15B is a new, lowcost, fixed wavelength UV detector for liquid chromatography. At the standard 254-nm wavelength, the maximum noise is $\pm 1 \times 10^{-5}$ absorbancy units while drift is less than $2 \times 10^{-4}$ absorbance units. Range settings down to around 0.0001 AUFS are included, with response times of $0.2,0.5$ and 1.0. Other features of the LC-15B include a push-button event mark, large digital readout and wide zero baseline adjustment range.

Circle No. 142 on Reader Service Card.

-A high sensitivity auto-ranging electrostatic 'fieldmeter' has recently been developed by John Chubb Instrumentation of Cheltenham. The JCL 101 gives stable measurement of electric fields in the vicinity of 'static' charges on insulating or conducting surfaces.

Circle No.143 on Reader Service Card.

- Agarose IEF is a highly purified agarose optimized for isoelectric focusing by charge balancing. Gradient drift is reduced to a minimum to give high resolution, stable $p \mathrm{H}$ gradients and efficient isoelectric focusing. Agarose IEF is produced by Pharmacia.

Circle No.144 on Reader Service Card.

These notes are based on information provided by the manufacturers. For further details circle the numbers on the Reader Service Card bound inside the journal.
- Ulex europaeus agglutinin I (UEA I), a plant lectin recently claimed to be superior to antibody to factor VIII as an endothelial cell marker, is available from Vector Laboratories. UEA I has been shown to identify vascular endothelia in kidney, liver, pancreas, lung, skin, brain, placenta, umbilical cord and cultured cells as well as various tumours of endothelial origin. Unlike anti-factor VIII antibodies, UEA I can be used equally well on snap frozen or paraffin embedded tissues. Several detection systems are available including fluorescein or rhodamine conjugates for fluorescent microscopy, and affinity purified antibodies to UEA I or biotin-labelled UEA I for biotin/avidin-based histochemical techniques.

Circle No.145 on Reader Service Card.

- The Thermex interface from Columbus Instruments converts an Apple II Plus or Apple IIe computer into an automatic printing 16-channel thermometer. As sensor, it utilizes J, K or T thermocouples. Resolution in the biological temperature range is $0.1^{\circ} \mathrm{C}$. In other temperature ranges accuracy of $0.2 \%$ full-scale is achieved by individually calibrated thermocouples. A special calibration program is available to allow the user to calibrate and linearize thermocouple probes in any desired range. Thermex has built in cold junction compensation. Biological probes are available for rectal, intravenous and implantable applications for use in animals. A video monitor displays current temperatures in all channels.

Circle No.146 on Reader Service Card.

- An ultra-stable stirrer speed in the range $0-1,250$ r.p.m. is possible with the ADI 1012 stirrer control unit. Manufactured by Applikon B.V., the controller is specially suited for use in fermentation vessels. With the aid of the ADI 1012's remote speed control input, stirrer speed can be regulated automatically with respect to the culture's oxygen content.

Circle No.147 on Reader Service Card.

- Antibodies for the detection of oncogene protein products and related antigens - such as the epidermal growth factor receptor - are now available from Oncor. The antibodies are intended for use in immunofluorescence, immunoprecipitation and enzyme-linked assays. The range consists of: $\mathrm{ABmyc.1}$, ABras.1, ABsrc.1 and AB EGF-R.1. Each antibody is supplied with sufficient product to perform 50 RIP-PAGE assays.

Circle No. 148 on Reader Service Card.
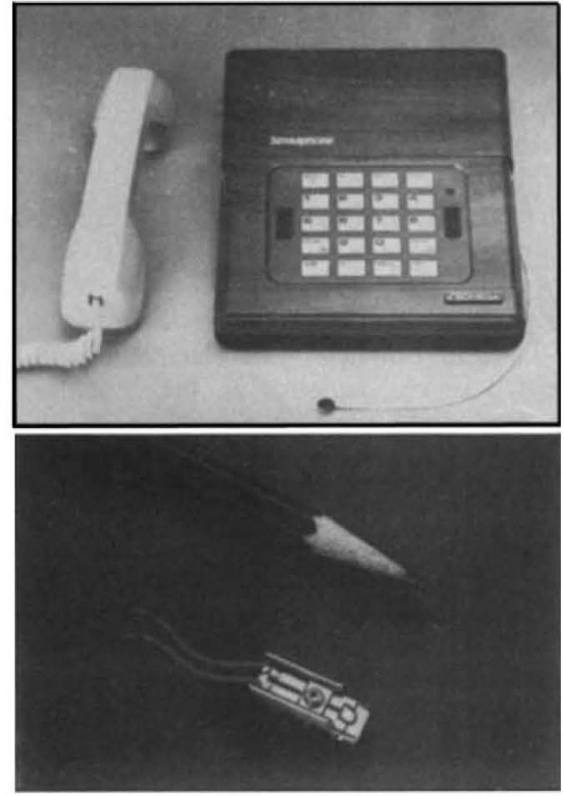

The Omega laboratory monitor (top) and Spectra-Physics new laser

-Constant process monitoring is possible with the new Omega LM-1000 laboratory monitor with voice simulator. It monitors a wide variety of process and laboratory conditions via a standard telephone jack. The LM1000 will monitor conditions such as: room air temperature or ambient sound levels - the LM- 1000 can detect a process deviation alarm or presence of excess noise due to vibration. Alert conditions can be checked, for example: limit switch status on computer controlled machinery; status of valve actuated switches; pressure limit switches; and operation of solid state switching devices with control machinery. The LM-1000 automatically reacts to deviations from set conditions by phoning, in sequence, up to four pre-programmed numbers until the message is received.

Circle No. 149 on Reader Service Card.

- A new range of safety coated glass carboys in sizes up to 12 gallons is available from Wheaton Safety Co. The 'second skin' glass carboys are coated with an impact resistant, high tear thermoplastic transparent, translucent or opaque providing impact protection to reduce breakage potential and increasing manual handling stability. In the event of container breakage, the coating safely contains dangerous chemicals, and radioactive and biohazardous materials long enough for proper disposal.

Circle No.150 on Reader Service Card. 